\title{
Personal Construct Experience of Tionghoa Community in Aceh Reality
}

\section{Personal Construct Experience of Tionghoa}

Safuwan

Faculty of Medicine, Department of Psychology, Malikussaleh University, Lhoseumawe, Aceh, Indonesia

Muhammad Ali

Faculty of Social Science and Political Science, Department of Communication

Science, Malikussaleh University, Lhokseumawe, Aceh, Indonesia

\begin{abstract}
Purpose - This paper presents a research personal construct experience of the Tionghoa community, shaping the social reality of Aceh enactment. The case of the Tionghoa community in Banda Aceh and Lhokseumawe city, Aceh Province, Indonesia, is studied to evaluate their ability to construct their experience and socialize them.

Design/Methodology/Approach - This research is designed using a phenomenological approach which is oriented to cross-cultural studies.

Findings - The personal construct experience of Tionghoa community includes attitudes, assumptions, self-concept, and interpretation of Aceh reality. Through the construction of their experience, Tionghoa community is able individuals who have a number of unique desires and identities, and also as a social person who is ready to blend in Aceh.

Research Limitations/Implications - This reality is practiced by almost all Tionghoa in Aceh so that the social behavior that appears on the surface tends to make them stable, calm, courageous, and worry-free of Aceh people.

Originality/Value - This personal construct experience of Tionghoa community will have policy making both in Aceh in particular and in Indonesia, as multi-ethnic, religions, languages, and cultural consistency.
\end{abstract}

Keywords Tionghoa community, Islamic Sharia Law, social psychology

All papers within this proceedings volume have been peer reviewed by the scientific committee of the Malikussaleh International Conference on Multidisciplinary Studies (MICoMS 2017).

\section{Introduction}

Practicing by Islamic Sharia in Indonesian becomes phenomenal because there is always debate among the ruling elite, parliament, or by certain social groups. In the preamble of UUD 1945, the annulment of the "Piagam Jakarta," the dissolution of constituents and the $\mathrm{DI} / \mathrm{TII}$ crackdown in various regions is a bitter record for the implementation of movement

(C) Safuwan, Muhammad Ali. Published in the Emerald Reach Proceedings Series. Published by Emerald Publishing Limited. This article is published under the Creative Commons Attribution (CC BY 4.0) licence. Anyone may reproduce, distribute, translate and create derivative works of this article (for both commercial and non-commercial purposes), subject to full attribution to the original publication and authors. The full terms of this licence may be seen at http://creativecommons.org/ licences/by/4.0/legalcode

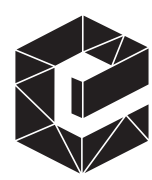

Emerald Reach Proceedings Series Vol. 1
pp. $193-198$ Emerald Publishing Limited 2516-2853 DOI 10.1108/978-1-78756-793-1-00024 
Proceedings of MICoMS 2017 in Indonesia. Similarly, since 2000, various responses to certain social groups in Aceh have been generated. Differences in assessment not only occur among non-Muslims in some Muslim Aceh. Commonly, the Acehnese conceiving the Sharia is still in the narrow sense, limited to wearing headscarves, Arabic writings, hand-cuts to thieves, or the splendor of celebratory rituals on symbolic Islamic holidays (Kontras, March 2002). When Sharia was enacted in Aceh, there was fear and concern among non-Muslims that lest the implementation of Islamic law that was also required for non-Muslims so that their religious freedom would be disrupted and even lost (Tambunan, 2002). The non-Muslim perceptions of Sharia were something unattractive because of the no significant impact on their daily activities (Safrilsyah, 2004).

All of these opinions are identical so the non-Muslim groups are considered the most disadvantaged of Sharia because they feel restricted to space, and they do not feel free to live their lives. According to the author, such an assumption is a false and questionable opinion, because it is not explained how individuals from non-Muslim groups construct their experience in shaping the social. How attitude conditions, assumptions, self-concept, and interpretation of non-Muslim individual reality become a life experience is also not revealed. Whereas these two contexts are very important to be described in a heterogeneous of the methodology used by the individual or social group in shaping its reality so that it is known how far they are harmed by the existing legal system of the region. Therefore, the ability of each individual non-Muslim group to construct its experience in Aceh reality is a major issue in this article.

The most important indicator of the individual or social group to arrive at a conclusion is to rely heavily on the ability of the construction of experience to form social circumstances surrounding it. And this issue in the view of author needs its entirety so as to gain clear knowledge about the individual or social group condition. This reality is practiced by almost all Tionghoa people through the empowerment of attitudes and assumptions, self-concept, and the interpretation of reality in an integrated way to generate subjective understanding (self-efficacy) and objective interpretation (self-assimilation) to the existing environmental situation. Therefore, the findings of this study can contribute significantly to multi-ethnic in the guy taking of policymakers and learn for society.

\section{Literature review}

\subsection{Tionghoa and Islam}

Historically Chinese immigrants entered long before the Dutch entered Indonesia. The arrival of the ethnic Chinese into Indonesia is motivated by the uncertain economic, political, and security factors of the country. Chinese immigrants entering Indonesia initially are not in large numbers, but individually or in small groups residing in coastal ports of Java. The Chinese had known Islam in the first century of the Hijrah (seventh century $\mathrm{CE}$ ) because geographically China crossed the Arabian Peninsula, especially the southern part of China, so surprising that in South China, there are the largest pockets of Islam, such as Canton, Zhangzhou, Quanzhou, and other South China regions (Al Qurtuby, 2003).

While China's interaction with Aceh began in 1415 (year 13/Yong Le) through the voyage by Admiral Cheng Ho across the Malacca Strait to Samudra Pasai (Aceh), and Cheng Ho's entourage was picked up by King Zainal Abidin-Raja Samudra Pasai (Yuanzhi, 2000). However, the expansion of Tionghoa in Aceh only occurred in the nineteenth century CE or 1875 which was imported by the Dutch colonial from Hongkong to be employed in various sectors, such as the Dutch army, opium merchant, watch house inspector, brothel, or another worker (Veer, 1977). 


\subsection{Tionghoa in Aceh}

In reality, the non-Muslim population in Aceh is very small, that is, less than $1.50 \%$, with details; Protestant Christian 0.96\%, Catholic 0.14\%, Buddhist 0.16\%, and Hindu 0.02\% (Abubakar, 2006, p. 142). While they spread throughout the region of Aceh and they come from various tribes in Mainland, China, Hakka, Hokkien, Teochiu, Kwong, and others. Ethnic Tionghoa in Aceh is limited only in urban (city/county) only. Similar to Tionghoa community at Banda Aceh and Lhokseumawe city, Aceh province, Indonesia, their focus was around in the city. Tionghoa community at Banda Aceh city mostly resides in Kampung Mulia Peunayong, Pasar Aceh, Seutui, and in the Pante Riek Lamreung Buddhist Complex. While in Lhokseumawe city, this social group also lives in downtowns, such as in Simpang Kramat and Pusong. While the population of ethnic Chinese in Banda Aceh amounted to 500 people and Lhokseumawe was as many as 200 people. Although their population is not much, they are at Banda Aceh or Lhokseumawe city successfully carrying out trading activities in various types, such as workshops, electronics, studio printing photo, handphone, two/four wheel dealers, auto parts /motorcycles tools/building materials, and others.

The profile of Tionghoa residents living in Aceh today is a generation of 20/21 cE Chinese who came by volunteering generally from North Sumatra to trade to Aceh, while the crossbred after the Dutch colonial departure from Aceh also still exist, but it is quite difficult to ascertain how many. For the people of China, their migration is not the purpose of to spread religion, but to meet the needs of the economy. Therefore, in order to achieve their business objectives, they seek to mingle, adapt, or even marry local people.

\section{Methods}

\subsection{Research design}

This research is designed to approach of phenomenological research that is oriented to cross-cultural studies by means of Social Psychology analysis. The use of this method is intended to fit the characteristics of the problem and the objectives studied, that is, the nonMuslim experience in Aceh, Indonesia.

\subsection{Research focus}

This study is limited to aspects of attitude, assumptions/knowledge, self-concept, and individual interpretation as the main basis for the construction of experience non-Muslim in Aceh.

\subsection{Data sources}

To obtain the main data, direct observation in reality and in-depth interviews with some Tionghoa community at Banda Aceh and Lhokseumawe city, Aceh, Indonesia was done. And then, while other data were supported by using documentation data: books, research reports, and other relevant journals.

\subsection{Validity inspection of data}

This study uses data validity checking techniques with triangulation, that is, data sources, researchers, and methods-by utilizing something other from outside data for checking or comparison needs for the data found. The validity of this research data can be tested empirically. 


\section{Proceedings of \\ MICoMS 2017

\section{Results} \\ 4.1. Attitude}

Highlighting the Chinese people's living systems in Aceh province, Indonesia, impressed that Chinese people made adjustments only to government regulations by making identity cards, paying taxes, or trying not to break the law. While assimilation of process played by Tionghoa community, in reality, is limited to the interests of business activities only. Interestingly, despite such social conditions, issue of social inequality, anti-Chinese sentiment, discrimination, terror or physical violence on ethnic Chinese descent never happen in Aceh. This condition is different from Tionghoa cases in Java or regions other in Indonesia.

Tionghoa community of attitude in Aceh the beginning causes to be confused and somewhat unstable, as the process of socialization of Islamic Sharia is not fully known Aceh. The situation is also exacerbated by issues of provocation from among the elite or unscrupulous leader religion irresponsibly. However, when runs for about six months, the confusion of Tionghoa people's declined because what is rumored by political opportunists or sentimental groups against religion is unreasonable and only cheap propaganda. The factual evidence can be analyzed from Tionghoa who are trapped in clothing raids by Sharia Police, and at least the experience has got socialization about the condition of Sharia of Islam the question and answer communications to friends who are Moslem.

\title{
4.2. Assumption
}

In ethnically, culturally, or religiously diverse societies, and other problems, the assumptions can arise spontaneously or after studying environment. In relation to this discourse, diverse opinions may emerge as the response of a diverse ethnic, religious, linguistic, or cultural community. This difference in opinion will reflect the true mood of Acehnese society's assumptions that is the changing socio-political landscape in Indonesia. Almost every Chinese's opinion is oriented towards their activities:

\begin{abstract}
The activities of Tionghoa are merely trading and what policies is a matter of government we respect its community. Maybe misunderstanding that we read in the newspaper care traders, trading to live. Other people why fear with Islamic shari'a. I'm sure Tionghoa community everywhere never deal with religious issues because we have our own religion. In Indonesia, many Chinese are Muslims. But if in Aceh, I don't know, maybe a little because the Chinese are also many clans and different origins. There may also be married to the Acehnese. But even though we are not married here we have considered Aceh a place to live and die. So life, so practice Islamic Sharia, no problem for Chinese people because staying here is long, not ethnic riots or religious matters, just be safe.
\end{abstract}

From this statement, it appears that the reflection on Sharia in Aceh is not an important issue in the spiritual movement of this social group. View of reality does not base their views on innocent prejudice or wishing earlier on an object in their sphere of life different from their beliefs. However, their opinions are more focused on their activities.

\subsection{Self-concept}

Understanding of the person himself is usually interaction and communication of people with objects, objects, situations, or so-stated self-concept. These social phenomena, in reality, can be analyzed through various speeches, such as I have self-esteem, your self is different from me, self-introspection, and so forth. Other times we also encounter person-toperson conversations that lead to mockery of others, disrespect of others, or always see others low, for example, he is incompetent, he is inappropriate or he is not level, etc. Whereas what people are communicating or thinking about others, the position of others, or others is 
social attribution. The analysis and guesswork of people against others is the wrong selfconcept. A false self-concept leads to displeasure, envy or hate. Therefore, the appearance of person-to-person behavior in relationships between new human beings can create a harmonious and serási atmosphere when each person is himself, recognize himself, understand himself, interpret himself, and position himself correctly.

Descriptions of self-concept of Tionghoa generally oriented towards the attribution, cognition, perception, attitude, and the surrounding environment where they live. Physically and visibly this ethnicity in Aceh is easily recognizable from skin color, slanted eyes, language, daily activities, or pockets of their residence. While psychologically like, perception or self-concept, not with spontaneity can be known through interaction and active communication with this social group. The experience felt in life in Aceh, the knowledge of their self-concept Sharia, also formed and developed in its own accord with each Chinese of social construction.

Related data of Tionghoa towards general can be described this here.

Implementation of Sharia of government affairs, we follow it. Our work is merchants who are looking for food, yes trade to live for a long time. My children were born in Aceh all we have become Acehnese people too, going where. Islamic Sharia is normal and does not matter to us. I and my family are Buddhists but I'm not worried about the rules. For the Tionghoa itself, usually a Chinese prayer event on every 15th. It depends on the belief also because the Chinese are also different clans and religions here. Then at New Year of Chinese, we also celebrate with Tionghoa. For me as a Chinese who Aceh remains a Chinese, Muslim affairs, and our government affairs don't interfere.

\section{Discussion}

Islamic Sharia in the Indonesian context is interesting for review always public debate, from the political elite, ruler, social-political analyst to certain groups. This Tionghoa reflection in the analysis of social psychology can be regarded as a snippet of social behavioral circumstances that relate these attitudes, individuals or social groups. Similarly, the conducive situation felt by these social groups tends to be pleasant without causing negative behavior from other components of the Achenes people. This phenomenon of social attitudes could review of social life system that is democratic, friendly, and still strong bonds of brotherhood in society. Admitted or not, this condition's character and historical sociological and geographical areas' actualization of Sharia system is meaningfully understood and applied in the life together.

Social psychologist Mead (1934) says human interaction, environmental conditions, and human existence as beings operate the aspects of mind, self in reality. Mead (1934) argues that the human self in this really focuses as an object on "me," and himself as the subject is referring to "I." Individuals "I" will look back, or to the actions, they have just implemented and think about their implications for maintaining their identity. The connect "I" and "me" is interdependent dynamically, since most of the actual actions of the individual will reveal the "me." And this is multi-ethnic or of various colors. What individuals do solely to build selfexperience is a comfortable life in it.

\section{Conclusion}

The non-Muslim community in Aceh is very much correlated with the extent of the ability of the experience construction to shape its reality. The fundamental problem of the construction of human experience is how attitudes, assumptions, self-concepts, and interpretations of existing social realities. Taking of the non-Muslim Tionghoa case in Aceh 
Proceedings of is highly dependent on the individual's ability experience in the social it. The individual's MICoMS 2017 ability experience is oriented towards attitudes, assumptions, self-concepts, and the interpretation of reality in an integrated manner related; sociological, historical, economic, psychosocial, and cultural analyzes developed in Aceh people in general.

This fact is adopted by almost all Tionghoa community by empowering their personalities as subjects and social objects. As a subject, "me" with specific human rights. While the social object side, portray themselves as "I" general obligation. Almost all Tionghoa community encountered felt capable of presenting themselves as subjects and social objects.

\section{References}

Abubakar, A. (2006). Syariat Islam di Provinsi Nanggroe Aceh Darussalam: Paradigma, Kebijakan dan Kegiatan. Dinas Syariat Islam Provinsi NAD, Banda Aceh.

Al Qurtuby, S. (2003). Arus Cina_Islam-Jawa: Bongkar Sejarah Atas Peran Tionghoa dalam Penyebaran Agama Islam di Nusantara Abad XV \& XVI. Inspeal Alhimsa Press, Yogyakarta.

Mead, G.H. (1934). Mind, Self, and Society: From the Standpoint of a Social Behaviorist. C.W. Morris (Ed., Vol. I, pp. 329-336). The University of Chicago Press Ltd, London.

Safrilsyah (2004). Persepsi Masyarakat Non Muslim Terhadap Pemberlakuan Undang-Undang Syariat Islam di NAD (Studi Kasus di Kodya Banda Aceh). Laporan Penelitian IAIN Ar-Raniry, Banda Aceh.

Tambunan, R.F. (2002). "Pelaksanaan Syariat Islam: Sebuah Refleksi Pengalaman Gereja". dalam F. Nur (Ed.), Syariat di Wilayah Syariat, pp. 174-181. Dinas Syariat Islam NAD, Aceh.

Veer, P. Van’t (1977). “Perang Belanda di Aceh”. Depdikbud D.I Aceh, Banda Aceh.

Veeger, K.J. (1993). “Realitas Sosial: Refleksi Filsafat Sosial atas Hubungan Individual-Masyarakat dalam Cakrawala Sosiologi”. Gramedia, Jakarta.

Yuanzhi, K. (2000). “Muslim Tionghoa”. In Cheng Ho. Pustaka Populer Obor, Jakarta.

\section{Corresponding author}

Safuwan can be contacted at safuwan@unimal.ac.id 